\title{
THE GENUS TANYCYPRIS (CRUSTACEA, OSTRACODA) IN THE WEST INDIES
}

\author{
by \\ NICO W. BROODBAKKER \\ Institute of Taxonomic Zoology, University of Amsterdam, \\ P.O. Box 20125, 1000 HC Amsterdam, The Netherlands
}

\begin{abstract}
SUMMARY
A list of species that are, or probably have to be, assigned to the genus Tanycypris is given. A redescription is given of $T$. meridana (Furtos, 1936), a species originally described as Herpetocypris, from Yucatan (Mexico). This species was also found in Puerto Rico, two of the Lesser Antilles and two islands off the Venezuelan coast. The species is compared with other species of Tanycypris, with species of the subgenus Acanthocypris of Strandesia s.l., as defined by Broodbakker (1983), and especially with Strandesia venezolana Broodbakker, 1983, which seems to be intermediate between Tanycypris and Acanthocypris. Furthermore, a supplementary diagnosis of the genus Tanycypris is given. Tanycypris appears to be a widespread tropical genus, represented by few species with an extensive distribution.
\end{abstract}

\section{RÉSUMÉ}

On présente une liste des espèces appartenant (ou appartenant probablement) au genre Tanycypris. On donne une redescription de $T$. meridana (Furtos, 1936), espèce décrite du Yucatan, d'abord comme Herpetocypris. Cette espèce a été retrouvée à Puerto Rico, dans deux des Petites Antilles, ainsi que dans deux îles au large des côtes du Venezuela. On compare cette espèce avec d'autres Tanycypris, avec des espèces appartenant au sous-genre Acanthocypris (de Strandesia s.l., tel que défini par Broodbakker, 1983), et surtout avec Strandesia venezolana Broodbakker, 1983 espèce qui semble occuper une position intermédiaire entre Tanycypris et Acanthocypris. De plus, une diagnose supplémentaire du genre Tanycypris est fournie. Tanycypris se montre être un genre tropical à large distribution, représenté par un petit nombre d'espèces, elles-aussi à large distribution.

\footnotetext{
* Report 36 is published in the same issue of this journal.
}

\section{INTRODUGTION}

This article is part of a study on the tribe Cypricercini. The other parts (Broodbakker, 1983, 1984) dealt with the genus Strandesia. In the present article the genus Tanycypris, which is classified here with the tribe Cypricercini, as was suggested by Victor \& Fernando (1981) and discussed by Broodbakker (1983), is reviewed. All species that are or ought to be ascribed to this genus are listed and discussed. The genus is represented in the West Indies by the species $T$. meridana, which was incorrectly described as a Herpetocypris by Furtos (1936). This species is redescribed and compared with species of the genus Strandesia, and in particular with $S$. venezolana Broodbakker, 1983, which seems to occupy an intermediate position between Strandesia and Tanycypris (Broodbakker, 1983: 355).

\section{MATERIAL AND METHODS}

The species was only found in the epigean samples collected by the expeditions of Dr. P. Wagenaar Hummelinck (abbreviated as WH) to many Caribbean islands (1936-1973), and was not present in the wells and other groundwater habitats sampled by the Amsterdam Expeditions to the West Indian Islands. All material is deposited in the Zoölogisch Museum, Amsterdam (ZMA).

The descriptions of the chaetotaxy of the limbs are made according to the system of Broodbakker \& Danielopol (1982). The lengths of several segments and setae were measured, as well as carapace length. Measuring was done with a ruler on a sheet of white paper, on which the animals were projected by way of a camera lucida and a Leitz Dialux 20 EB microscope. Slides were made according to the method of Danielopol (1982). 


\section{TAXONOMIC PART}

Family CYPRIDIDAE Baird, 1845

Subfamily CYPRIDINAE Baird, 1845

Tribe Cypricercini McKenzie, 1971

Genus Tanycypris Triebel, 1959

Type-species: Tanycypris madagascarensis (Müller, 1898)

G. W. Müller (1898) described two species of ostracods, Cypris clavigera and C. madagascarensis, from Madagascar. In 1912 he placed these species in the genus Dolerocypris. Triebel (1959) showed that $D$. madagascarensis does not belong to Dolerocypris, and erected the new genus Tanycypris for the species.

Rome (1965) described a Tanycypris species from South Africa, which he considered to be the same as $D$. clavigera. However, the species described by Rome is much larger, does not possess spines at the posterior part of the valves, and is parthenogenetic. Furthermore, Rome (1965: 21) states that there is no spine visible in fig. 15 of Müller (1898: pl. XVI), which is simply not true. Considering the fact that the structure of the furca is very similar in the different species, as is the shape of the carapace, I strongly doubt that Rome was dealing with $T$. clavigera. Reexamination of the type-specimens will have to reveal their true affinity.

Petkovski, in the discussion following the congress paper of Rome (1969), declared that Dolerocypris pellucida Klie, 1932, also belongs in Tanycypris and that specimens which he identified as $T$. pellucida, coming from rice fields in Macedonia, were in his view identical with $T$. clavigera. Furthermore, in his opinion Dolerocypris marina Hartmann, 1965, described from a submarine freshwater spring in Chile, belongs in Tanycypris as well.

Victor \& Fernando (1981) provided a concise description of the genus Tanycypris, and discussed $T$. pellucida. They synonymized Strandesia camaguiensis Tressler, 1937, from the Philippines, also recorded from Japan by Okubo (1972), with $T$. pellucida from Sumatra. Moreover, they assume that $T$. pellucida and $T$. clavigera are different in the structure of the valves and the furcal attachment. In $T$. pellucida the ventral branch of the furcal attachment is reduced to a stump, while it is absent in $T$. clavigera.

In some samples from the West Indies a species was found with the carapace shape of a Stenocypris or Herpetocypris, but showing a dorsal eyelet in the furcal attachment, and a strongly serrate, symmetrical furca. On the ground of these characters and the reduced ventral branch of the furcal attachment, it would belong to the genus Tanycypris. Furthermore, the anterior seta of the furca is nearly as long as the anterior claw, the posterior seta is serrate, and the posterior claw is bent in anterior direction at $20 \%$ of its length. These furcal characters are also found in other Tanycypris species.

The species was compared with similar Ostracoda, described from South and Central America, and appeared to be the same as Herpetocypris meridana Furtos, 1936, described from Yucatan. This species has the same carapace shape, size, and furca. Unfortunately, Furtos did not describe many other characters.

There are two other species which may be identical with, but are at least closely related to, T. meridana. These species are: Strandesia pedroensis Tressler, 1949, from Brazil, and Herpetocypris bonettoi Ferguson, 1967, from Argentina. Both species were, however, very poorly described, which makes a reliable identification impossible. The species discussed are listed in table I, with some other data.

$T$. meridana is here redescribed, and its characters are compared with those of other Tanycypris species, and with those of Strandesia venezolana and S. longula Broodbakker, 1983.

\section{Tanycypris meridana (Furtos, 1936)}

(Figs. 1, 2)

Material. - WH 759, îles des Saintes, Terre-de-Haut, Mare Basse, temporary dug-out pool; dimensions: $18 \times 18 \times 0.5 \mathrm{~m}$; andesite, detritus; meadow-like, muddy, considerable growth of algae and water lilies; slightly 
TABLE I

List of species belonging or ascribed to the genus Tanycypris, distribution, carapace length, and authors who discussed or redescribed the species.

\begin{tabular}{|c|c|c|c|}
\hline Species & Geographical distribution (authors) & $\begin{array}{l}\text { oro' } \\
\text { found }\end{array}$ & $\begin{array}{l}\text { Length range } \\
\bigcirc \propto \text { specimens } \\
(\mathrm{mm})\end{array}$ \\
\hline Tanycypris bonettoi (Ferguson, 1967) & Argentina (= probably syn. with $T$. meridana) & - & $1.25-1.30$ \\
\hline Tanycypris camaguiensis (Tressler, 1937) & $\begin{array}{l}\text { Philippines (= syn. with } T \text {. pellucida; Victor \& } \\
\text { Fernando, 1981) }\end{array}$ & - & 1.36 \\
\hline Tanycypris clavigera (Müller, 1898) & Madagascar & + & $0.75-0.80$ \\
\hline Tanycypris nec clavigera Rome, 1965 & South Africa & - & 1.18 \\
\hline Tanycypris madagascarensis (Müller, 1898) & Madagascar (Triebel, 1959) & + & $1.52-1.66$ \\
\hline Tanycypris marina (Hartmann, 1965) & Chile (Petkovski, in Rome, 1969) & + & $1.02-1.03$ \\
\hline Tanycypris meridana (Furtos, 1936) & $\begin{array}{l}\text { Mexico, Puerto Rico, La Désirade, Îles des } \\
\text { Saintes, Los Testigos, Isla Margarita }\end{array}$ & - & $1.28-1.37$ \\
\hline Tanycypris pedroensis (Tressler, 1949) & Brazil ( = probably syn. with $T$. meridana) & - & 1.33 \\
\hline Tanycypris pellucida (Klie, 1932) & $\begin{array}{l}\text { Sumatra, Philippines, Russia, Japan, Malaysia } \\
\text { (Bronstein, 1947; Okubo, 1972; Victor } \\
\text { Fernando, 1981) }\end{array}$ & - & $1.20-1.46$ \\
\hline
\end{tabular}

polluted by cattle; chlorinity $70 \mathrm{mg} / \mathrm{l} ; 6-\mathrm{II}-1964$; about 300 specimens used for redescription. Accompanying Ostracoda: Cypretta sp., Cypridopsis sp.

Other stations: WH 13, Isla Margarita, Estanque Lato, W. of Boca del Rio, Macanao; dug and dammed, permanent, stagnant pool; dimensions: $80 \times 50 \times 3$ (?) m; detritus and schist debris; sand and mud; few algae with some Chara and Najas; clear and colourless; chlorinity $70 \mathrm{mg} / 1$; 20-V-1936; 21 specimens (length range of carapaces: 1.20 to $1.28 \mathrm{~mm}$ ). Accompanying Ostracoda: Potamocypris hummelincki Klie, 1933, Chlamydotheca hummelincki hummelincki Triebel, 1961, and Physocypria affinis Klie, 1933.

WH 30, Los Testigos, Poza del Morro de la Iguana; dug and dammed, stagnant, semipermanent pool; dimensions: $10 \times 6 \times 1.5 \mathrm{~m}$; on weathered granitic rock; sand and mud; very few algae, much Lemna; turbid and greyish; chlorinity $460 \mathrm{mg} / \mathrm{l}$; 14-VI-1936; 6 specimens (length range of carapaces: 1.22 to $1.25 \mathrm{~mm}$ ). Accompanying Ostracoda: Rudjakoviella prolongata (Triebel, 1962), Chlamydotheca hummelincki hummelincki, Physocypria affinis, Heterocypris margaritae Margalef, 1961, and Potamocypris hummelincki.

WH 743, La Désirade, pool near the Source du Léproserie; dug-out, muddy pool on loamy semicultivated soil; dimensions: $2 \times 1 \times 0.25 \mathrm{~m}$; no vegetation; chlorinity about $500 \mathrm{mg} / \mathrm{l} ; 24-\mathrm{I}-1964 ; 1$ specimen (carapace length: $1.31 \mathrm{~mm})$. No accompanying ostracods.

WH 706, Puerto Rico, Laguna Cartagena, Valle de Lajas; part of large lake; dimensions: $100 \times 50$ ? $\times 1 \mathrm{~m}$; semipermanent; inundated; on semicultivated weathered soil; muddy bottom; phanerogams; chlorinity $30 \mathrm{mg} / \mathrm{l}$; 18-IX-1963; 4 specimens (length range of carapaces: 1.30 to $1.32 \mathrm{~mm}$ ).
Geographical distribution known. Yucatan (Mexico), Puerto Rico, La Désirade, Îles des Saintes, Los Testigos, Isla Margarita.

\section{Redescription}

Only females of this species have been found. Relative lengths of some setae and segments are given in table II.

Carapace (figs. 1, 2A):

The carapace is smooth, sparsely hairy, and whitish transparent in dead specimens. The available specimens were strongly decalcified because of preservation in formalin. The outer surface is very finely striate, as can be seen in fig. 1E. Hinge adont. Muscle scars as typical of the Cypridinae. In dorsal view greatest width from one-third to two-thirds of the length, being about $30 \%$ of the length (fig. 1D). In lateral view greatest height at about $60 \%$ of the length, being $40 \%$ of the length. Left valve slightly larger than the right one.

Carapace very elongate. The dorsal margin is slightly bent and passes smoothly in the broadly rounded anterior margin, and the less rounded posterior one. The decline of the dorsal margin is stronger posteriorly. The dorso- 

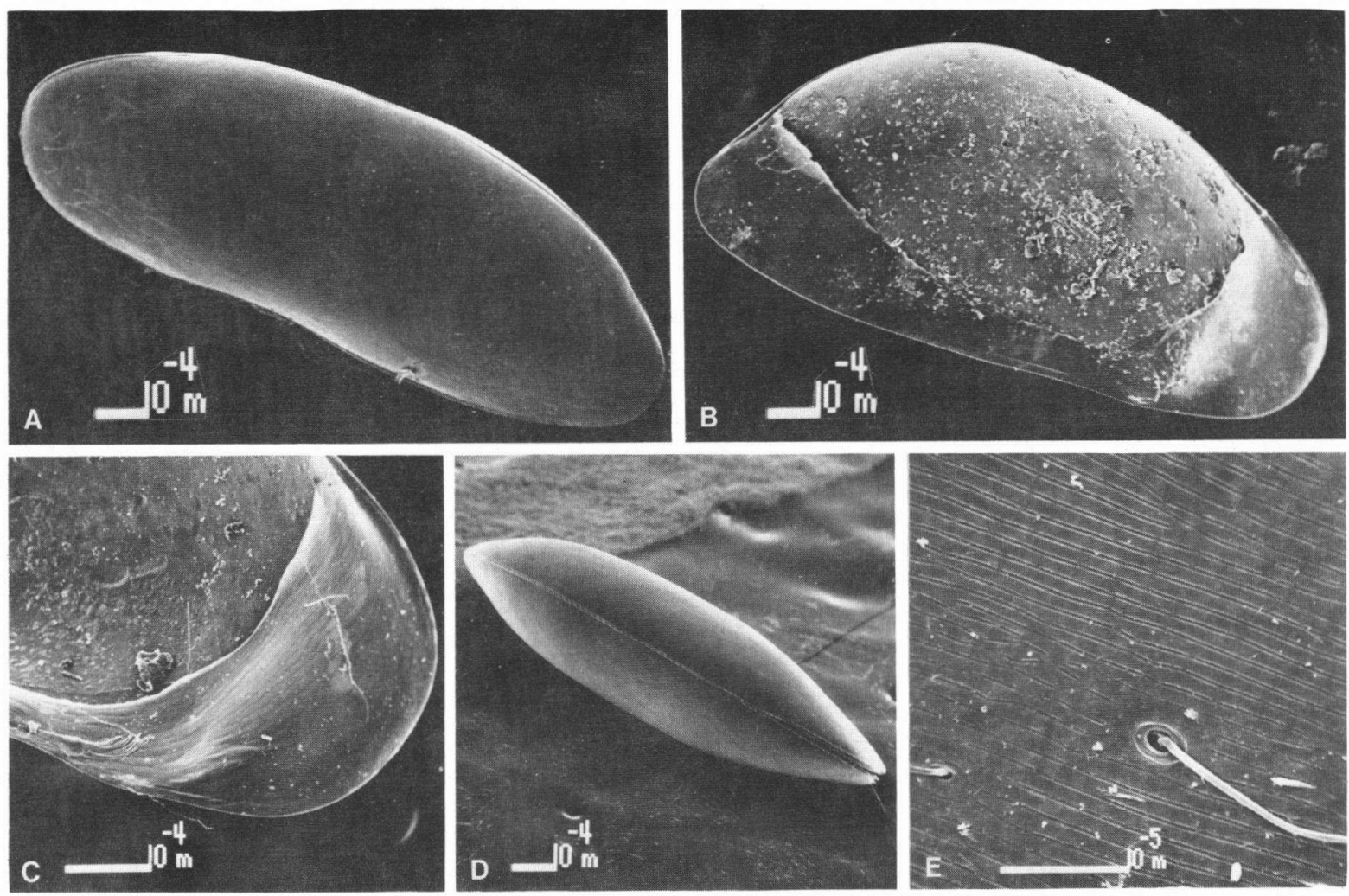

Fig. 1. Tanycypris meridana (Furtos, 1936) (WH 759, Terre-de-Haut, Mare Basse, Iles des Saintes; $\&$ specimens): A, complete animal in lateral view; B, left valve from inside; C, detail of inner side of anterior part of the left valve; D, carapace in dorsal view; $\mathrm{E}$, detail of surface structure of the valves.

posterior part forms an angle of $45^{\circ}$ with the ventral margin, but is anteroposteriorly rounded. Ventral margin only slightly sinuate. There is no distinct lip-like projection anteroventrally, in contrast to that in Strandesia species. In neither of the valves marginal pore canals are visible.

Duplicature very wide anteriorly, the inner margin strongly declining in ventral direction. Ventrally the inner margin smoothly inclines in posterior direction, forming an elongate large duplicature posteriorly. The duplicature is largely grooved (figs. 1B-C, 2A). Selvage and flange are not pronounced. The carapace is more hairy at the ventral edges.

The mean length of the carapace is $1.27 \pm 0.02 \mathrm{~mm}(n=81)$ in WH 759 , îles des Saintes (length range: 1.18 to $1.34 \mathrm{~mm}$ ), and $1.24 \pm 0.02 \mathrm{~mm}(n=19)$ in WH 13, Margarita (length range: 1.20 to $1.28 \mathrm{~mm}$ ). The length of the few specimens which have been found in the other localities ranges from 1.22 to $1.31 \mathrm{~mm}$, falling within the length range of the specimens from Îles des Saintes.

The specimens found by Furtos (1936) measured $1.37 \mathrm{~mm}$ in length. The specimens described as Strandesia pedroensis by Tressler (1949) measured $1.33 \mathrm{~mm}$ in length, and the specimens described as Herpetocypris bonettoi by Ferguson (1967) measured 1.25 to $1.30 \mathrm{~mm}$ in length.

Antennule (fig. 2B):

I: A- $1 m(\mathrm{pu}), \mathrm{P}-2 l(\mathrm{pu}) / \mathrm{II}: \mathrm{A}-1 s, \mathrm{P}-\mathrm{r} / \mathrm{III}: \mathrm{A}-1 s$, P-1s/IV: A-2l, P-1s/V: A-2l, P-1l-1s/VI: A-2l, P-2l/VII: D-1l $\left(\mathrm{y}_{\mathrm{a}}\right)-1 s-2 l$.

Rome's organ is very small, translucent, and shaped as a hollow tube (fig. 2B). The structure and chaetotaxy is the same as in Strandesia species. The aesthetasc $y_{a}$ is very long, and the 
short setae of segments II to VI are very short. The segments III to VII are long and slender.

Second antenna (figs. 2C-D):

The structure and chaetotaxy are the same as in $S$. longula, with long slender claws, which are not extremely serrate. Claw $\mathrm{G}_{2}$ does not have stronger teeth, in contrast to this claw in $S$. venezolana. The claws are hooked at the tops. The long swimming setae are barely reaching the tips of the claws. The three exopodal setae are short. The segments of the antenna are long and slender. The aesthetascs $\mathrm{Y}$ and $\mathrm{y}_{3}$ are $30 \%$ and $23 \%$ of the length of $E I$, respectively. The $z$-setae are just not reaching the tips of the claws. The other setae are practically the same as in $S$. longula. The longest exopodal seta is much shorter than in $S$. longula and $S$. venezolana. $\mathrm{G}_{1}$ is longer as compared with $\mathrm{E}$ (II + III), a feature common in the subgenus Neocypris, but not in Acanthocypris, to which $S$. longula and $S$. venezolana belong.

Mandibular palp (Mdp) (fig. 2E):

I: In- $1 m-2 m\left(\mathrm{~S}_{1,2}\right.$ : $\left.\mathrm{pu}\right)-\alpha / \mathrm{II}: \operatorname{In}-3 m(\mathrm{pu})-\beta(\mathrm{pu})-$

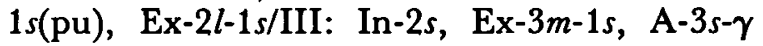
(pu)/IV: D-2m(cs:ser)-1s(cs)-3s.

The structure and chaetotaxy are practically the same as in most Strandesia species, but for a few exceptions. Segment III is comparatively longer than in Strandesia. Seta $\gamma$ is long and slender, $63 \%$ of the length of segment III, and plumose at one side. In most Strandesia species it is wider and pappose, but in $S$. venezolana it is likewise long and slender, but more strongly plumose on two sides. The nameless seta of segment $I$ is long, as in $S$. venezolana, and not short as in $S$. longula. Setae $\alpha$ and $\beta$ are as in many other Strandesia species, seta $\alpha$ being thin and delicate, and $\beta$ being broad and plumose. Setae $\alpha$ and $\beta$ are 63 and $43 \%$ of the length of segment III, respectively.

Maxillula (Mxu) (fig. 2F):

The chaetotaxy and structure are the same as in Strandesia. The second segment of the maxillular palp (Mxup II) is as elongate as in $S$. venezolana, but longer than in the other West Indian
Strandesia species. The first segment of the maxillular palp (Mxup I) and the third masticatory process are even more elongated than in Strandesia. The chelate setae (cs) of Mxup II are 1.7, and those of Mastic 3 are 1.6 times the length of Mxup II, which is the same as in $S$. venezolana, longer than in $S$. longula, but shorter than in most other West Indian Strandesia species. The two chelate setae of Mastic 3 are serrate at two sides.

Maxilla (Max) (fig. 2K):

Pr: A-2s(a:pu)/Exo: P-6m(pu)/Mastic: D-12?s $(\mathrm{pu}) / \mathrm{E}: \mathrm{D}-2 s(\mathrm{pu})-1 m(\mathrm{pu})$.

Two plumose ' $a$ ' setae are present. The setae ' $b$ ' and ' $d$ ' could not be found. The exopodite consists of six plumose setae. The protopodite as well as the endopodite are long and more slender than in Strandesia. The distal part of the protopodite is strongly twisted and stick-like on its most narrow side.

Thoracopod 1 (T 1) (fig. 2G):

The structure and chaetotaxy are the same as in Strandesia. The segments are somewhat more elongate than in Strandesia, especially the first endopodal segment. The relative lengths of the segments are comparable with those in the West Indian Strandesia species. The claw is relatively short, being 2.5 times the length of E II, which is as long as in $S$. venezolana, but relatively shorter than in the other West Indian Strandesia species.

Thoracopod 2 (T 2) (fig. $2 \mathrm{H}$ ):

The structure and chaetotaxy are the same as in Strandesia. The seta of E I and the medial seta of E (II + III) are 72 and $40 \%$ of the length of E I, respectively, the same relative lengths as in $S$. longula and $S$. venezolana.

Furca (Fu) (fig. 2L):

The furca is strongly serrate with seven groups of spines at the posterior side, and two rows of very minute spines along the lateroexterior sides. One row runs parallel to the strong spines and very close to it, the other one parallel and along the middle of the ramus. The ramus is 16 


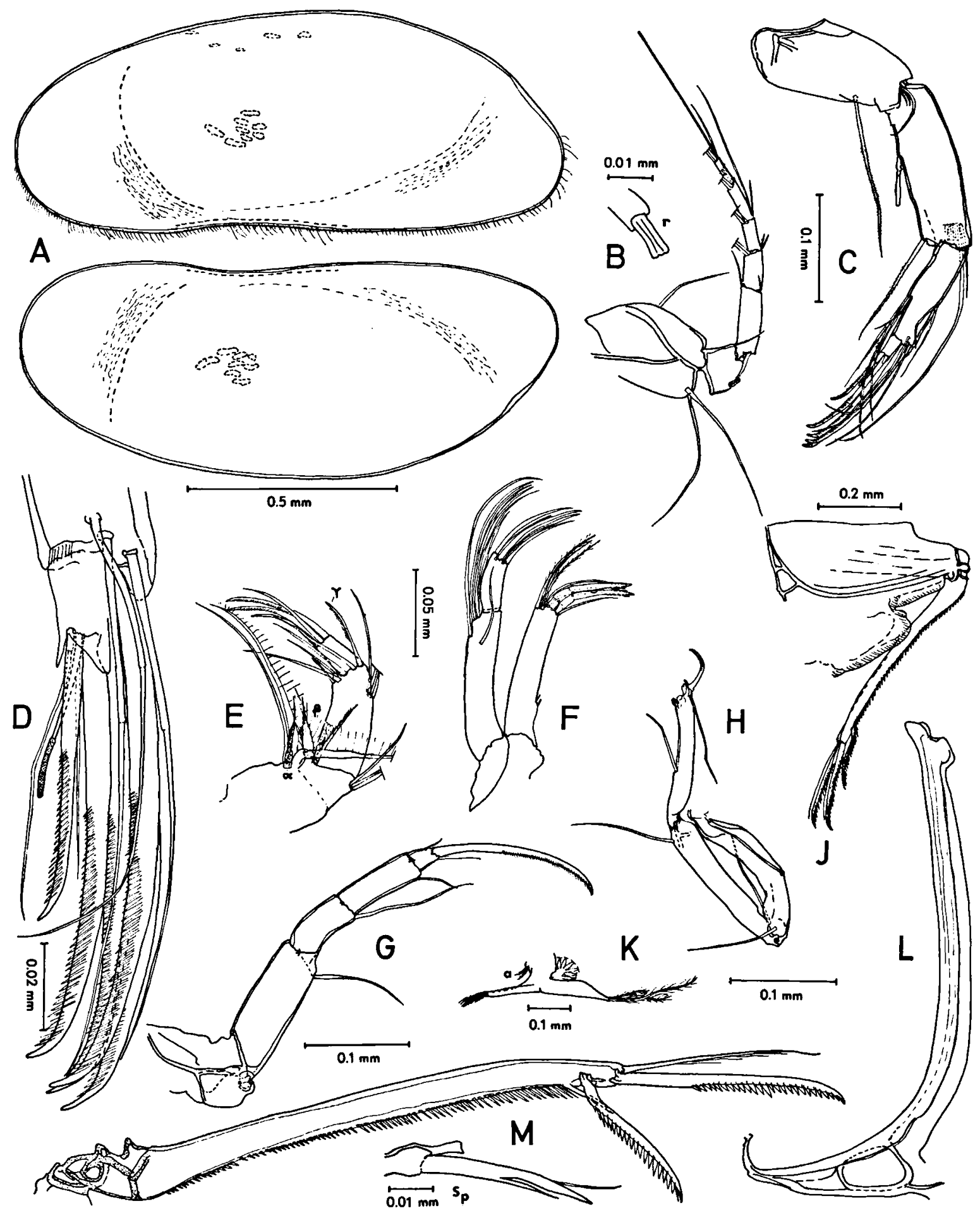

Fig. 2. Tanycypris meridana (Furtos, 1936) (WH 759, Terre-de-Haut, Mare Basse, Îles des Saintes: A-E, G-M, ९ no. 1; F, $९$ no. 2): A, left and right valve in lateral view; B, antennule with detail of Rome's organ (r); C, D, second antenna and detail of distal claws; E, mandibular palp; F, maxillular palp; G, H, first and second thoracopod; J, posterior part of the body; K, maxilla; $L$, furcal attachment; $M$, furca, with detail of posterior seta $\left(s_{\mathrm{p}}\right)$. 
TABLE II

Relative lengths of some setae and segments of appendages of Tanycypris meridana, and of two West Indian species of Strandesia, $S$. venezolana and $S$. longula, for comparison. Abbreviations used: eye = eyelet, le = length; ms = medial shaft; swim = swimming bristle; $v b=$ ventral branch; $w=$ width. For further abbreviations, see Broodbakker \& Danielopol, 1982: 114.

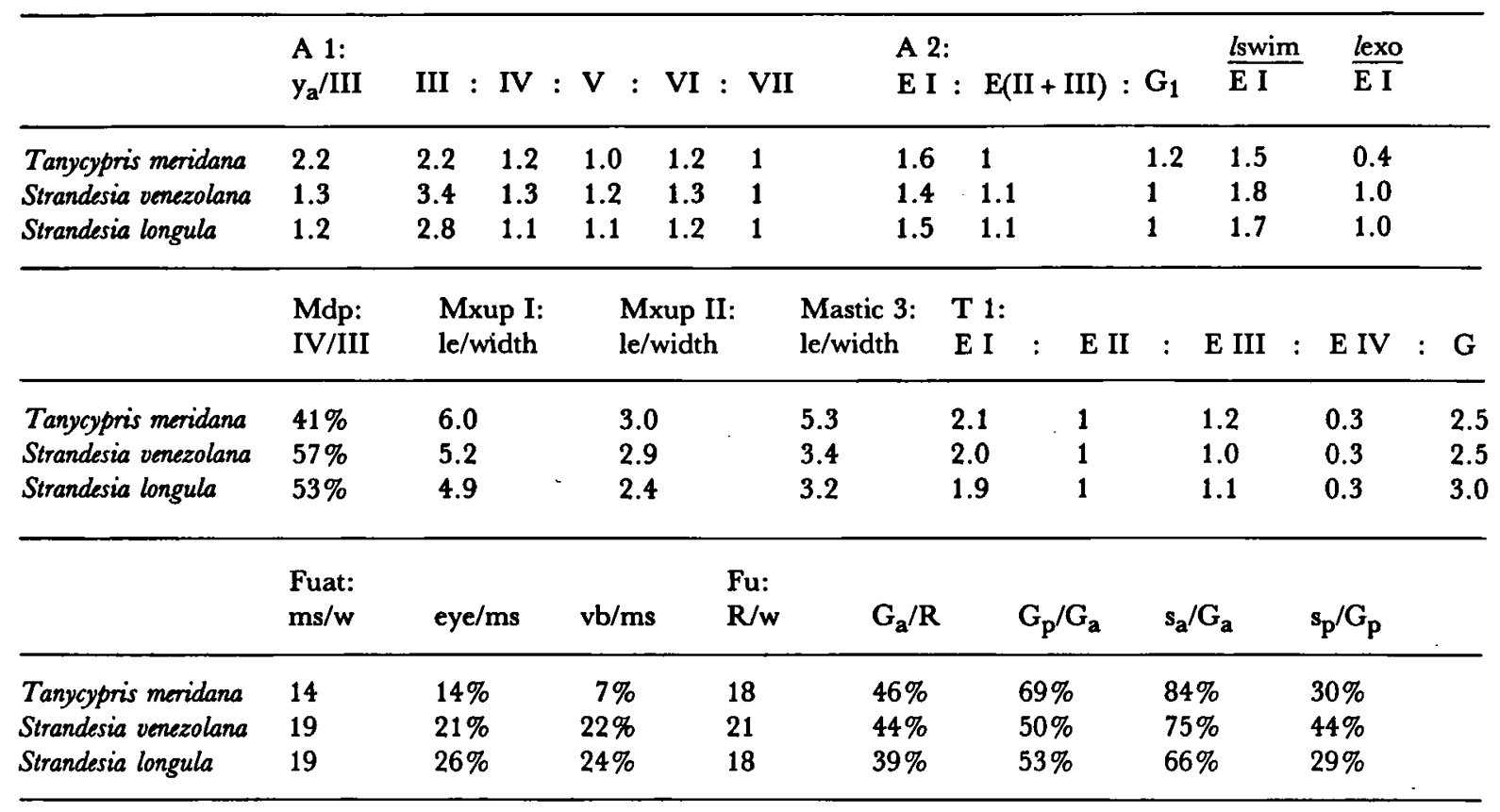

to 18 times as long as wide, depending on what is used as the basis of measuring. There is a complicated structure of sclerifications at the attachment point of the furcal attachment. The anterior claw $\left(G_{a}\right)$ is strongly pectinate for twothirds of its length, and the posterior claw $\left(G_{p}\right)$ for $80 \%$ of its length. The posterior seta is short, strong, with one spine and one setule, and fused with the ramus. The anterior seta $\left(s_{a}\right)$ is long and plumose.

The anterior claw is practically straight and only slightly bent at the top. The posterior claw is bent in anterior direction at $20 \%$ of its length. The ramus is only slightly bent.

The furca is practically the same as in the other Tanycypris species, and shows most affinities with the furca in species of the subgenus Acanthocypris of Strandesia, especially with that of $S$. (A.) venezolana.

Furcal attachment (Fuat) (fig. 2L):

The furcal attachment is strong, wide, and has two eyelets, an oval large, and a triangular small one. The ventral branch is reduced to a small spine. It is typical of the genus Tanycypris.

Female copulatory organs (fig. 2J):

These have no special characters. They are somewhat shifted in anterior direction, as in $S$. longula and $S$. venezolana.

\section{Ecology:}

$T$. pellucida was found in ponds, ditches and rice fields (Victor \& Fernando, 1981). T. meridana was always found in pools, and once in inundated semicultivated land, with a muddy, or sandy and mudded bottom, at a chlorinity up to $500 \mathrm{mg} / \mathrm{l}$. Furtos (1936) and Tressler (1949) do not mention the type of habitat in which the species was found. Ferguson (1967) collected his species in very shallow waters, with much submergent vegetation. Therefore the species is assumed to be truly epigean, with perhaps a preference for shallow, large waters with much 
vegetation since it was seldom found in pools, and never in wells.

\section{TAXONOMY OF TANYCYPRIS AND ACANTHOCYPRIS}

The genus Tanycypris shows most affinities with the subgenus Acanthocypris of Strandesia s.l., as defined in Broodbakker (1983). Most characters of this subgenus are also found in Tanycypris, especially the elongate carapace, the strongly serrate furca with short posterior seta, and the relatively short swimming setae of the second antenna. For each limb the characteristics of species of the genus Tanycypris will be given, and the differences with the subgenus Acanthocypris.

Antennule: The segments are slender, segment III is 2.5 to 3 times as long as wide.

Second antenna: The distal claws are long and slender, 1.2 to 1.3 times the length of $\mathrm{E}$ (II + III), this in contrast to the claws in Acanthocypris, and conform the claws in the subgenus Neocypris. In some species $\mathrm{G}_{2}$ is more strongly serrate than the other claws, as in $S$. venezolana. The swimming bristles just reach or just do not reach the tips of the distal claws.

Mandibular palp: Seta $\boldsymbol{\gamma}$ is slender, elongate and plumose at one side. It has about twice the length of segment IV. In $S$. venezolana seta $\gamma$ has the same shape, but is pappose. In Bradleystrandesia fuscata (Jurine, 1820) it is also slender, but in most Strandesia species it is shorter and broad.

Maxillula: The segments of the maxillular palp as well as the third masticatory process are more elongate than in Acanthocypris. However, S. venezolana also has a long Mxup II. In Tanycypris Mxup II is 2.7 to 3 times as long as wide. The chelate setae of the third masticatory process are usually serrate, excepting $T$. marina, and maybe $T$. clavigera sensu Müller.

Maxilla: There are two 'a' setae present, but ' $b$ ' and ' $d$ ' setae could not be found. Rome (1965) mentions that there are sparse setae, but does not refer to specific setae, except for the three endopodal ones. Both male and female maxillae are much more slender than in Acanthocypris, S. venezolana included. Especially the male endopodites are more or less elongate, rectangular (Müller, 1898; Hartmann, 1965). The exopodite consists of six setae, as in Strandesia.

Thoracopod 1: The segments are elongate and slender, the distal claw being comparatively short, as in $S$. venezolana, but in contrast to the other Acanthocypris species.

Thoracopod 2: No special characteristics. The length of the endopodites is about onequarter of the length of the carapace, as in Acanthocypris.

Furcal attachment: This part is large and stout, terminating in a large rounded eyelet, followed by a second smaller triangular eyelet. The ventral branch is absent or reduced. In $S$. venezolana there are two eyelets, but also a long ventral branch.

Furca: The characters of the furca are described in detail in the description of $T$. meridana. The serration of claws and ramus is as in Acanthocypris or even stronger, the anterior claw is 40 to $45 \%$ of the length of the ramus, the anterior seta is slightly shorter, and usually plumose. The posterior claw is 60 to $70 \%$ of the length of the anterior claw, and bent in anterior direction at the proximal part. The posterior seta is split or serrate.

Carapace: The carapace is extensively characterized by Triebel (1959). However, some changes in the diagnosis are necessary. The duplicature is not only wide anteriorly, but also posteriorly, as can be seen when figure $19 \mathrm{~b}$ (Triebel, 1959: Tafel 17) is examined. It was very difficult, if not impossible, to distinguish the posterior part of the duplicature under the microscope, but in the SEM photographs it is clearly visible (fig. 1B). In the description of $S$. venezolana this part of the duplicature has been overlooked as well, but upon reexamination it turned out to be the same as in $T$. meridana.

The carapace is elongate, the height being less than half the length. The anterior part is rounded, the posterior part can be rounded, or more or less acuminate, sometimes with small spines. 
From the description of the characters of the genus Tanycypris, and the differences with Acanthocypris and $S$. venezolana, it is clear that Tanycypris is closely related to the genus Strandesia s.l. and to the subgenus Acanthocypris in particular. $S$. venezolana shows many intermediate characters between Acanthocypris and Tanycypris, and is therefore postulated to be an intermediate species, as was already mentioned in Broodbakker (1983).

\section{DISTRIBUTION AND ZOOGEOGRAPHY OF TANYCYPRIS}

T. meridana is found in localities at considerable distances. It is probable, as in many other described freshwater ostracods from the West Indies, that it is more widely distributed than is presently known, since it was found in Yucatan (Mexico), Puerto Rico, some of the Lesser Antilles, and on two islands off the Venezuelan coast. If $T$. pedroensis and $T$. bonetto $i$ are proven to be the same species, it will mean that it is also present in Brazil and Argentina, so it probably has an extensive distribution throughout South America. If not, then at least all these South American species are very closely related.

This wide distribution is not uncommon, since $T$. pellucida was shown to be widely spread in Asia, by Victor \& Fernando (1981). From Africa not enough data on Tanycypris are available yet, but the species described by Rome (1965) as $T$. clavigera very closely resembles $T$. pellucida (see Petkovski, in Rome, 1969).

The genus Tanycypris seems to be a widespread tropical genus, represented by only a few species with an extensive distribution.

\section{ACKNOWLEDGEMENTS}

Dr. D. L. Danielopol is thanked for his support and the many contributions to my research project. Prof. Dr. J. H. Stock (coordinator of the West Indian project), Dr. L. Botosaneanu, and Drs. F. F. J. M. Pieters are thanked for critically reviewing the manuscript.

Dr. P. Wagenaar Hummelinck kindly placed his sampled material at our disposal.
The late Maarten Schoonoord made the SEM photographs, which were developed and printed by Louis van der Laan.

This study has been financed by the Netherlands Foundation for the Advancement of Tropical Research (WOTRO; The Hague).

\section{REFERENCES}

Bronstein, Z. S., 1947. Faune de l'URSS. Crustacés II (1). Ostracodes des eaux douces. Fauna SSSR, (N.S.) 31: 1-334, pls. I-XIV (in Russian).

Broodbakker, N. W., 1983. The genus Strandesia and other Cypricercini (Crustacea, Ostracoda) in the West Indies. Part I. Taxonomy. Bijdr. Dierk., 53 (2): 327-368.

-, 1984 . The genus Strandesia and other Cypricercini (Crustacea, Ostracoda) in the West Indies. Part II. Carapace length, ecology, and distribution of two Strandesia species. Bijdr. Dierk., 54 (1): 1-14.

Broodbakker, N. W. \& D. L. Danielopol, 1982. The chaetotaxy of Cypridacea (Crustacea, Ostracoda) limbs: proposals for a descriptive model. Bijdr. Dierk., 52 (2): 103-120.

DANielopol, D. L., 1982. The preparation of ostracod limbs, for optical microscopy (dissection, staining and mounting procedures). In: R. F. Maddocks ed., Eighth International Symposium on Ostracoda, July 26-29, 1982. Programs and abstracts: 41-43 (Department of Geosciences, University of Houston).

Ferguson, E., 1967. Three new species of freshwater ostracods (Crustacea) from Argentina. Notul. Nat., 405: $1-7$.

Furtos, N. C., 1936. On the Ostracoda from the cenotes of Yucatan and vicinity. Publs. Carnegie Instn., 457: 89-115.

Hartmann, G., 1965. Zur Kenntnis des Sublitorals der chilenischen Küste unter besonderer Berücksichtigung der Polychaeten und Ostracoden. III. Ostracoden des Sublitorals. Mitt. hamb. zool. Mus. Inst., 62 (Suppl.): 307-384.

Müller, G. W., 1898. Wissenschaftliche Ergebnisse der Reisen in Madagaskar und Ostafrika in den Jahren 1889-95 von Dr. A. Voeltzkow. Heft II. Die Ostracoden. Abh. senckenb. naturforsch. Ges., 21: 257-296, pls. XIII-XIX.

-—, 1912. Ostracoda. Tierreich, 31: i-xxxiii, 1-434.

Oкuво, I., 1972. Strandesia camaguiensis Tressler, 1937 from Japan (Ostracoda, Cyprididae). Proc. Jap. Soc. Syst. Zool., 9: 1-6.

Rome, D. R., 1965. Crustacea: Ostracoda. In: B. HANSTRöm, P. Brink \& G. Rudebeck eds., South African Animal Life, 11: 9-58 (Swedish Natural Science Research Council, Stockholm).

- - 1969. Morphologie de l'attache de la furca chez les Cyprididae et son utilisation en systématique. In: 
J. W. Neale ed., The taxonomy, morphology and ecology of recent Ostracoda: 168-193 (Oliver \& Boyd Ltd., Edinburgh).

Tressler, W. L., 1937. Ostracoda. Int. Revue ges. Hydrobiol. Hydrogr., 34: 188-207.

1949. Freshwater Ostracoda from Brazil. Proc. U.S. natn. Mus., 100: 61-83.
Triebel, E., 1959. Zur Kenntnis der Ostracoden-Gattungen Isocypris und Dolerocypris. Senckenberg. biol., 40: 155-170, pls. 12-18.

Victor, R. C. H. Fernando, 1981. Freshwater ostracods (Crustacea: Ostracoda) of the subfamily Dolerocypridinae Triebel, 1961 from Southeast Asia. Zool. J. Linn. Soc., 72 (2): 107-116.

Received: 15 December 1983 